\title{
Efficient Reverse Genetic Systems for Rapid Genetic Manipulation of Emergent and Preemergent Infectious Coronaviruses
}

\author{
Adam S. Cockrell, Anne Beall, Boyd Yount, and Ralph Baric
}

\begin{abstract}
Emergent and preemergent coronaviruses (CoVs) pose a global threat that requires immediate intervention. Rapid intervention necessitates the capacity to generate, grow, and genetically manipulate infectious CoVs in order to rapidly evaluate pathogenic mechanisms, host and tissue permissibility, and candidate antiviral therapeutic efficacy. CoVs encode the largest viral RNA genomes at about 28-32,000 nucleotides in length, and thereby complicate efficient engineering of the genome. Deconstructing the genome into manageable fragments affords the plasticity necessary to rapidly introduce targeted genetic changes in parallel and assort mutated fragments while maximizing genome stability over time. In this protocol we describe a well-developed reverse genetic platform strategy for CoVs that is comprised of partitioning the viral genome into 5-7 independent DNA fragments (depending on the CoV genome), each subcloned into a plasmid for increased stability and ease of genetic manipulation and amplification. Coronavirus genomes are conveniently partitioned by introducing type IIS or IIG restriction enzyme recognition sites that confer directional cloning. Since each restriction site leaves a unique overhang between adjoining fragments, reconstruction of the full-length genome can be achieved through a standard DNA ligation comprised of equal molar ratios of each fragment. Using this method, recombinant CoVs can be rapidly generated and used to investigate host range, gene function, pathogenesis, and candidate therapeutics for emerging and preemergent CoVs both in vitro and in vivo.
\end{abstract}

Key words Coronavirus $(\mathrm{CoV})$, Reverse genetics, Severe acute respiratory syndrome coronavirus (SARS-CoV), Middle East respiratory syndrome coronavirus (MERS-CoV), Emerging, Preemergent, Bat coronavirus, Porcine epidemic diarrhea virus (PEDV)

\section{Introduction}

Human coronaviruses (HCoVs) were first identified in the 1960s $(\mathrm{HCoV}-229 \mathrm{E}$ and $\mathrm{HCoV}-\mathrm{OC} 43)$ and were primarily associated with mild upper respiratory tract infections with the potential to progress to a severe respiratory disease in young children, the elderly, and immunocompromised individuals [1]. Although additional $\mathrm{HCoVs}$ were known to circulate at this time, these strains were not culturable; therefore, $\mathrm{HCoV}-229 \mathrm{E}$ and $\mathrm{HCoV}-\mathrm{OC} 43$ 
infections modeled our understanding of $\mathrm{CoV}$ disease severity until 2003 [1]. In Southeast Asia, severe acute respiratory syndrome coronavirus (SARS-CoV) emerged in late 2002 and caused acute respiratory distress syndrome and an age-dependent mortality rate of $10-50 \%$, clearly demonstrating that $\mathrm{HCoVs}$ were emerging pathogens with pandemic potential [2]. The portent of a worldwide pandemic mobilized the scientific community, leading to robust public health intervention strategies that controlled the epidemic. Moreover, the outbreak spurred academic interest into CoV gene function and pathogenic mechanisms associated with SARS-CoVinduced disease, leading to the development of therapeutic countermeasures. Because of the availability of reverse genetics, robust in vitro replication, and in vivo animal models of human disease, SARS-CoV has become the most intensively studied prototype for $\mathrm{HCoV}$ research [3]. SARS-CoV research prompted the generation of novel animal models that have provided insight into (1) genetic changes in the SARS-CoV genome that modulate respiratory pathogenesis $[4] ;(2)$ the impact of SARS-CoV on host innate and adaptive immune responses $[5,6] ;(3)$ the role of host genes in regulating SARS-CoV pathogenesis in mice $[4,7]$; and (4) novel strategies for the development of vaccines and therapeutic countermeasures [3].

Two novel HCoVs (NL63 and HKU1) were identified shortly after the emergence of SARS-CoV [8-10], and nearly a decade later, in 2012, the world saw the emergence of Middle East respiratory syndrome coronavirus (MERS-CoV) (Fig. 1). MERS-CoV causes acute respiratory distress syndrome (ARDS), severe pneumonia-like symptoms, and multi-organ failure, with a case fatality rate of $\sim 36 \%$ [11]. Human cases of MERS-CoV have been predominantly observed in Saudi Arabia and the Middle East. MERS-CoV-infected individuals have also traveled internationally, illustrating the potential for global spread. For example, a South Korean native returning home from the Middle East in May 2015 initiated an outbreak that infected 186 people, resulting in $20 \%$ mortality and a nationwide economic crisis [12]. Transmission of MERS-CoV has been mostly observed among health care workers in the hospital setting. Accumulating evidence indicates that Middle Eastern individuals working in close contact with dromedary camels are at increased risk of acquiring MERS-CoV [13]. Camels are suspected to be intermediate hosts between bats and humans that can repeatedly allow for reemergence of MERS-CoV in the human population. Though camels show only mild symptomology during MERS-CoV infection, zoonotic CoV infections can be highly pathogenic in animals. Demonstrated recently by the emergence of a porcine $\mathrm{CoV}$ in the United States, porcine epidemic diarrhea virus (PEDV) has caused severe disruption to the pork industry with the deaths of tens of millions of animals in the first 2 years and a $>90 \%$ mortality rate [14] (Fig. 1). PEDV, 


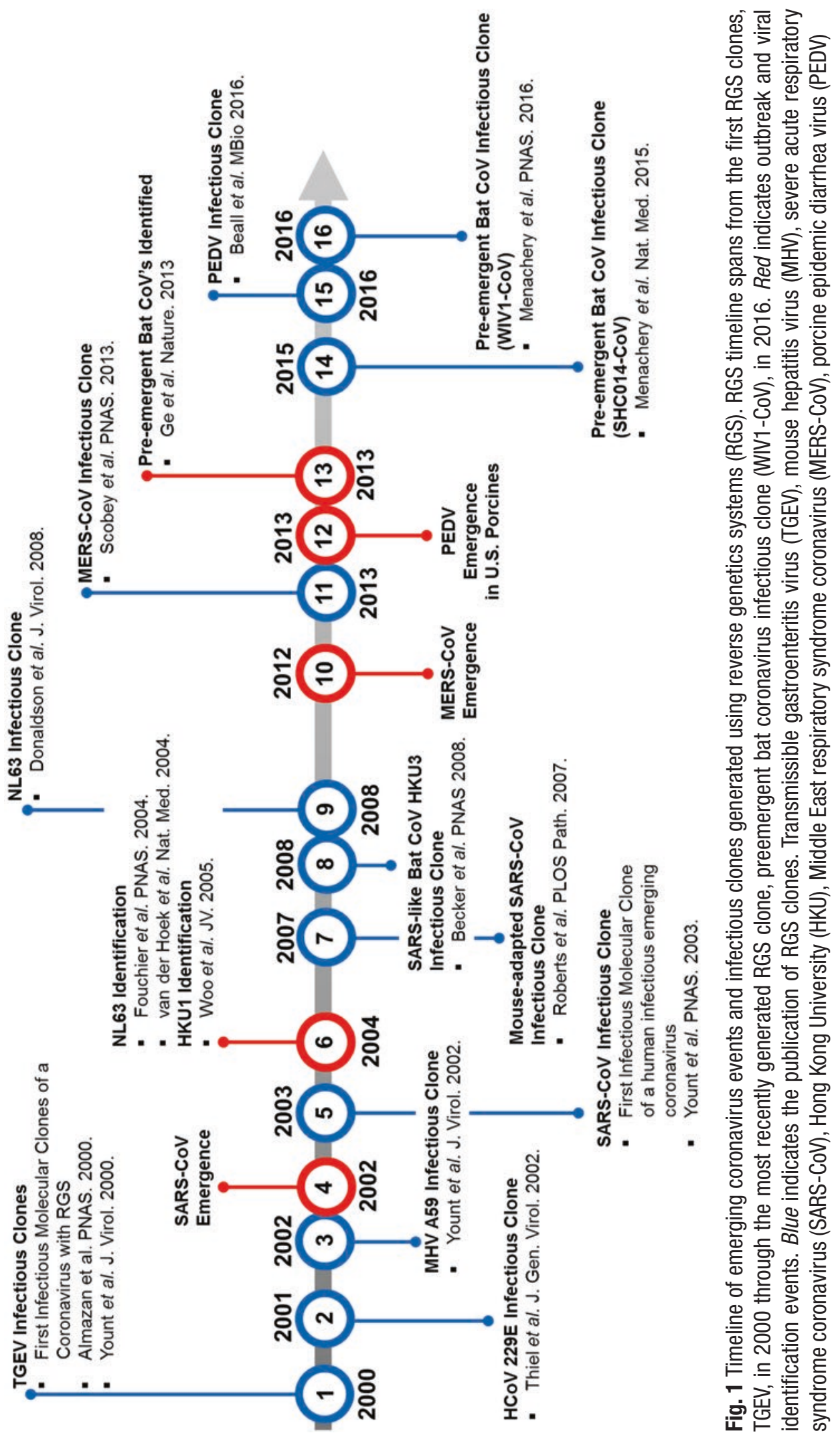


MERS-CoV, SARS-CoV, HCoV NL63, HCoV HKUl, and $229 \mathrm{E}-\mathrm{HCoV}$ are thought to have emerged from a bat reservoir, while OC43-HCoV is thought to have originated among bovine coronaviruses. In 2013 preemergent SARS-like CoVs were identified in horseshoe bats and found to be poised for entry into the human population [15] (Fig. 1). Importantly, much of the $\mathrm{HCoV}$ research over the last 15 years has been possible because of the capacity to generate infectious clones using highly efficient reverse genetics platforms [16], coupled with robust small animal models of human disease $[17,18]$.

Reverse genetic systems for coronaviruses were difficult to achieve because of the large size of the viral RNA genome, genome stability in bacterial vectors, difficulty in driving full-length $30 \mathrm{~kb}$ RNA transcripts in vitro, poor transfection efficiencies, and low infectivity of the viral genome. In 2000, the first molecular clone was developed for transmissible gastroenteritis virus (TGEV), using targeted splice junctions to increase genome stability in lowcopy baculovirus vectors [19] (Fig. 1). A few months later, our group published an alternative TGEV reverse genetic strategy [20], and then again applied this technique for the group 2 murine coronavirus [21]. A final innovation in $\mathrm{CoV}$ molecular clone design was the insertion of full-length $\mathrm{HCoV} 229 \mathrm{E}$ molecular clone into vaccinia virus in 2001 [22]. Each approach has proven to be a potentially powerful system to probe the role of $\mathrm{CoV}$ genes in replication and pathogenesis $[3,23,24]$. This review primarily focuses on the reverse genetic strategy developed in the Baric laboratory, a technology that partitions the $\mathrm{CoV}$ genome into discrete fragments, and uses class IIS and IIG restriction endonucleases to systematically and seamlessly assemble full-length cDNA genomes of CoVs. After in vitro transcription and transfection of full-length genomes into permissive cells, recombinant viruses are recovered which contain the genetic content of the molecular clone.

Although the reverse genetic system (RGS) described here achieved prominence shortly after the emergence of SARS-CoV [16], this platform has been used to generate CoV infectious clones that span nearly the entire breadth of the Coronaviridae family, including pathogenic viruses from groups $\mathrm{la}$ and $\mathrm{lb}$ of the alphacoronaviruses and groups $2 \mathrm{a}, 2 \mathrm{~b}$, and $2 \mathrm{c}$ of the betacoronaviruses (Fig. 1). The entire CoV fragments are joined by type IIS or IIG restriction sites (e.g., BglI, SapI, and BsaI) that support directional, seamless ligation into full-length genome (Fig. 2). For type IIS (e.g., SapI) restriction enzymes, the recognition sequences are separated from its cleavage site by one or more variable nucleotides, leaving three to four nucleotide unique overhangs (Fig. 2). Thus, these enzymes leave 64-256 unique ends, providing directionality during multi-segment assembly. Moreover, the recognition site is not palindromic, allowing for seamless assembly of component cDNA clones into full-length genes and genomes. By orienting the 

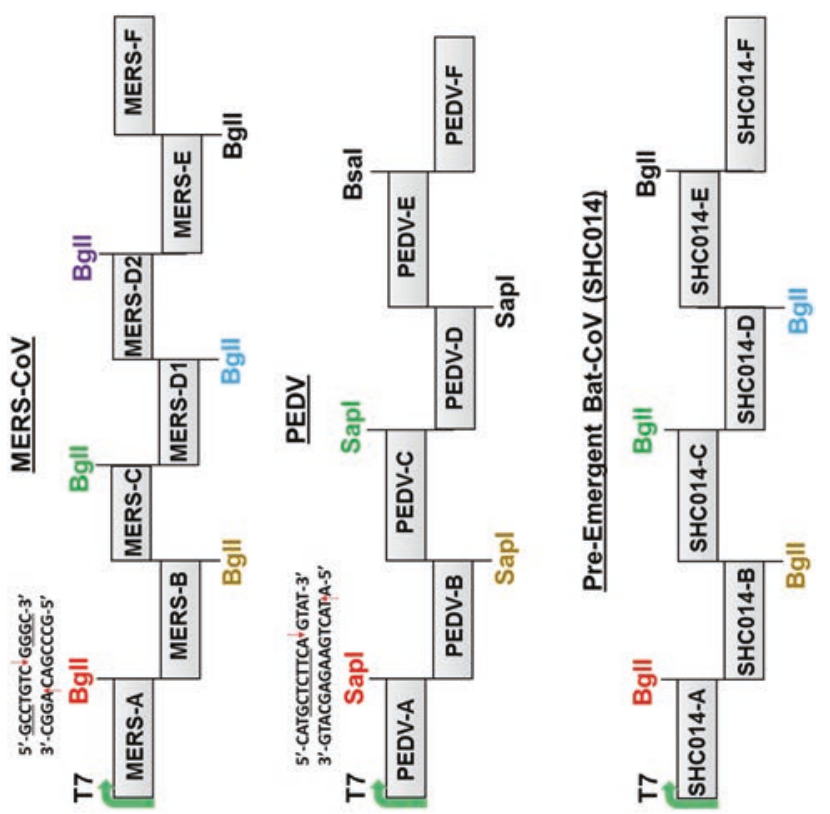

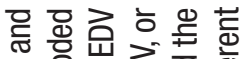

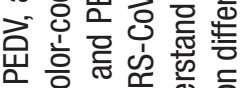
券

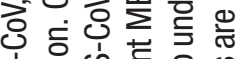

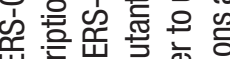
虫

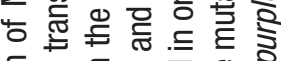
응으웡워

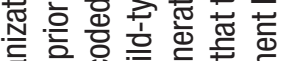

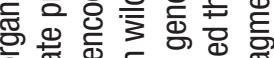
흥 힝 증을

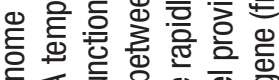

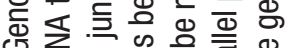

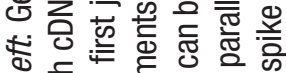

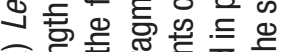
(1) ต่

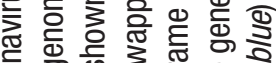

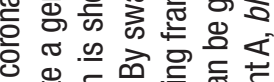

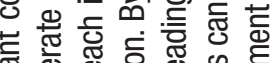

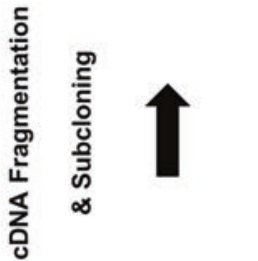

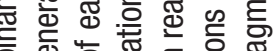

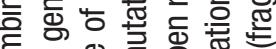

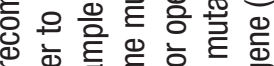
बㄴ छ

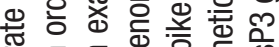
䏓.

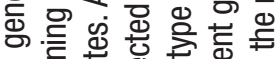

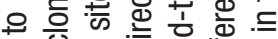
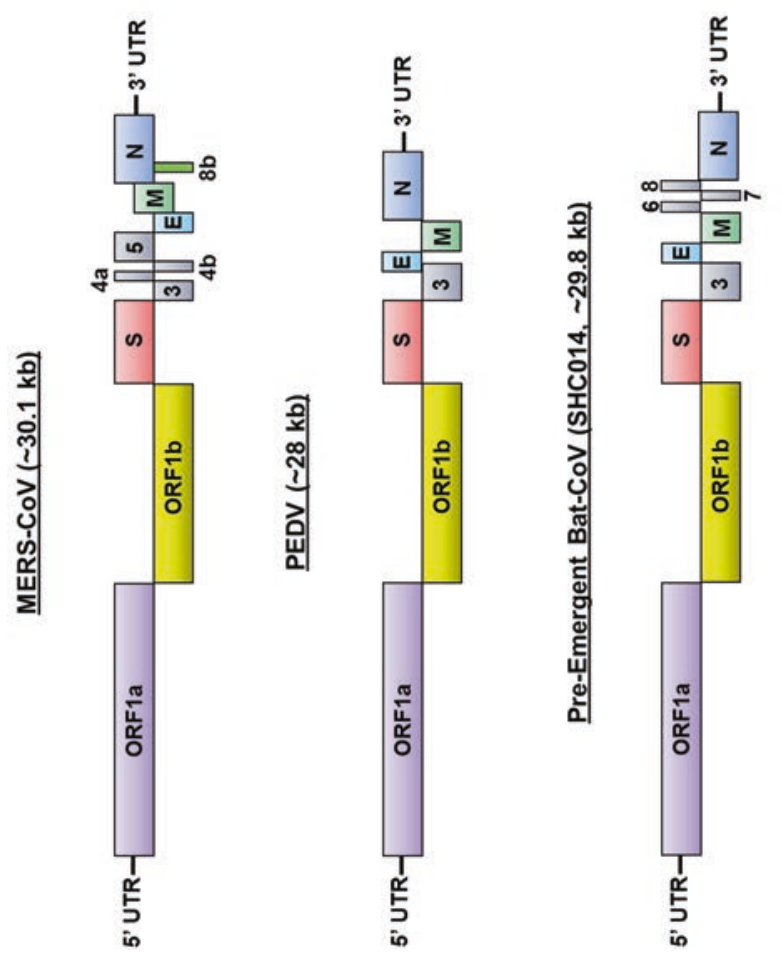

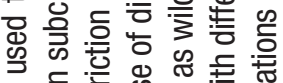

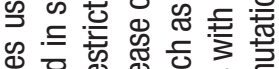

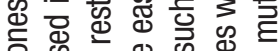

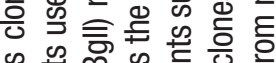

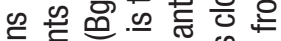

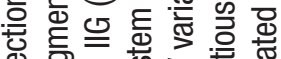
兽 这要

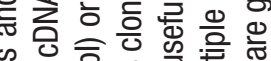

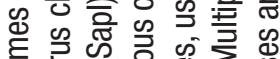

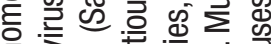

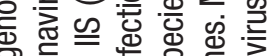
व 인

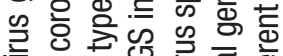

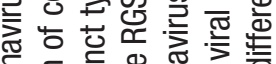

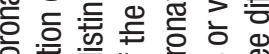

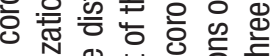

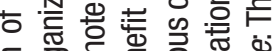

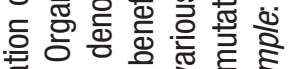

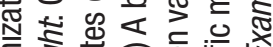

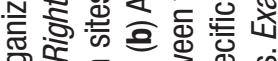
ㅎㅎㅁ ㄴㄷㄴ든

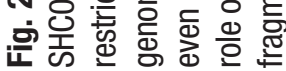



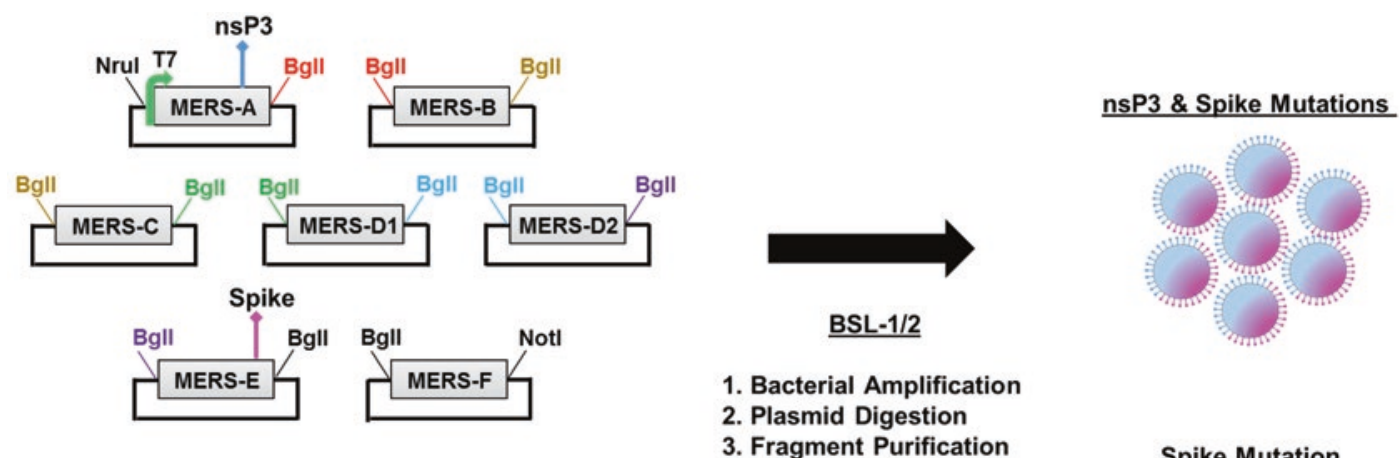

1. Bacterial Amplification

3. Fragment Purification
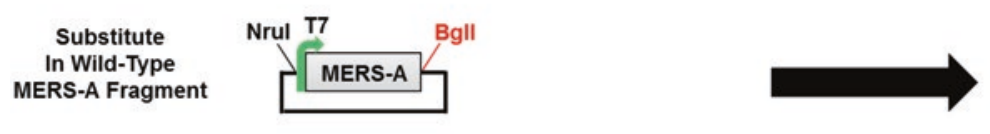

BSL-3

Spike Mutation

Substitute

MERS-F Fragment

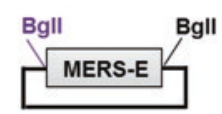

4. Fragment Ligation

5. Viral RNA Transcription

6. Electroporation of Viral RNA

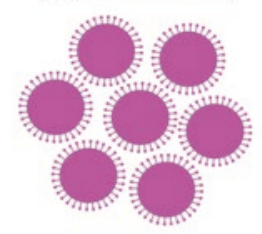

nsP3 Mutation
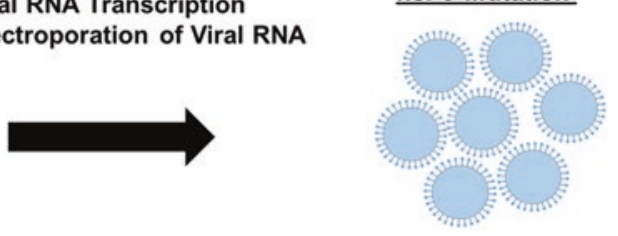

Fig. 2 (continued)

recognition sequence external to the cleavage site, upon digestion and ligation, the restriction site is lost, seamlessly joining the cDNAs, while preserving ORF integrity and sequence authenticity. A second approach uses type IIG (e.g., BgII) restriction endonucleases, which has a palindrome restriction site, bisected by a variable domain of five nucleotides and also leaves 64 different overhangs for directional assembly of large genome molecules (Fig. 2). In this instance, the restriction site is retained in the assembled product. As coronavirus genomes are unstable in bacteria, junctions are oriented within toxic sequence domains, thereby bisecting region toxicity and increasing component clone stability. Plasmids are digested with type IIS or IIG restriction enzymes to isolate each fragment of the $\mathrm{CoV}$ genome (Fig. 2). Fragments are then resolved on an agarose gel, purified, and ligated (Fig. 2). Following ligation, the coronavirus genome-length mRNA is in vitro transcribed from a T7 promoter added at the $5^{\prime}$ end of the $5^{\prime}$ UTR. In some instances, strong T7 stop sites are mutated to promote full-length transcript synthesis in in vitro transcription reactions [20]. Resulting genomelength mRNA is electroporated into a permissive mammalian cell line (Fig. 2). Cloning success and viral fitness can be measured by plaque assay and growth curves (Fig. 3). During viral replication 

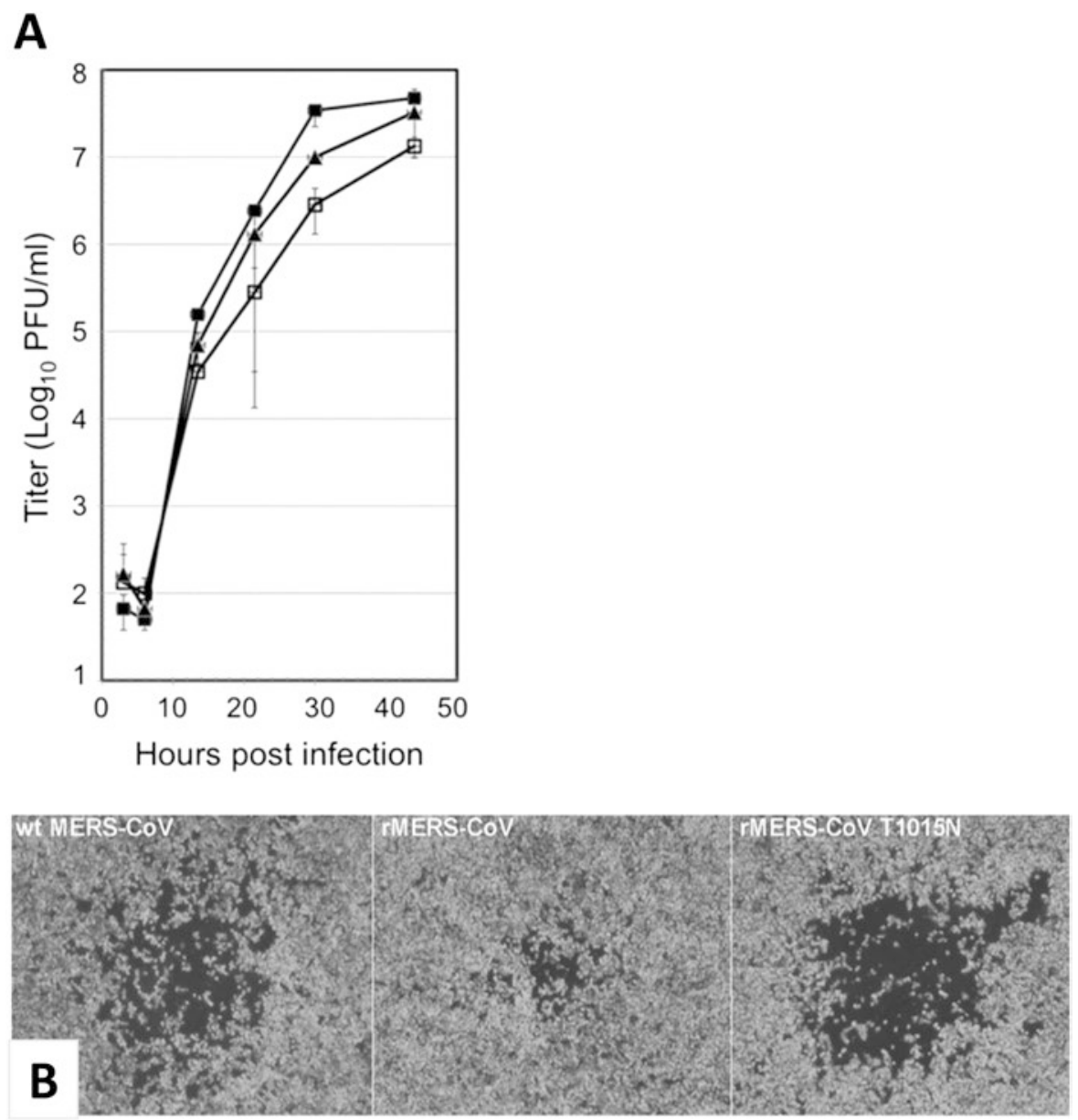

Fig. 3 Confirmation of MERS-CoV production and growth characteristics. (a) A comparison of growth curves in wild-type (filled square, MERS-CoV), recombinant MERS-CoV (open square, rMERS-CoV) and a recombinant MERS-CoV containing a tissue culture-adapted mutation in the spike gene (filled triangle, rMERS-CoV-T1015N). (b) A comparison of plaque formation in wild-type MERS-CoV, rMERS-CoV, and rMERS-CoV-T1015N. The recombinant MERS-CoV with the tissue culture adaptation cloned back in using RGS exhibits plaque sizes similar to wild-type MERS-CoV. All images reprinted from [25]

CoVs have the unique capacity to generate a nested set of subgenomic viral RNAs (sgRNAs) harboring similar 5' and $3^{\prime}$ untranslated regions (UTRs) (Fig. 4). Northern blot analysis of CoV RNA, and/or PCR of viral cDNA, affords visualization of sgRNA and confirmation of replication-competent virus (Fig. 4). The efficiency of RGS is exemplified by the fact that an infectious clone of SARS-CoV (icSARS) was generated and published [16] within weeks of the initial publication of the SARS-CoV Urbani strain sequence [26] (Fig. 1). The use of DNA synthesis companies to synthesize a full-length coronavirus genome was achieved in 2008, using $\mathrm{HCoV}$ NL63 as a model [27], and then applied to MERS-CoV and various bat SARS-like CoVs in 2008, 2013, 2015, and 2016 [25, 28-30]. 


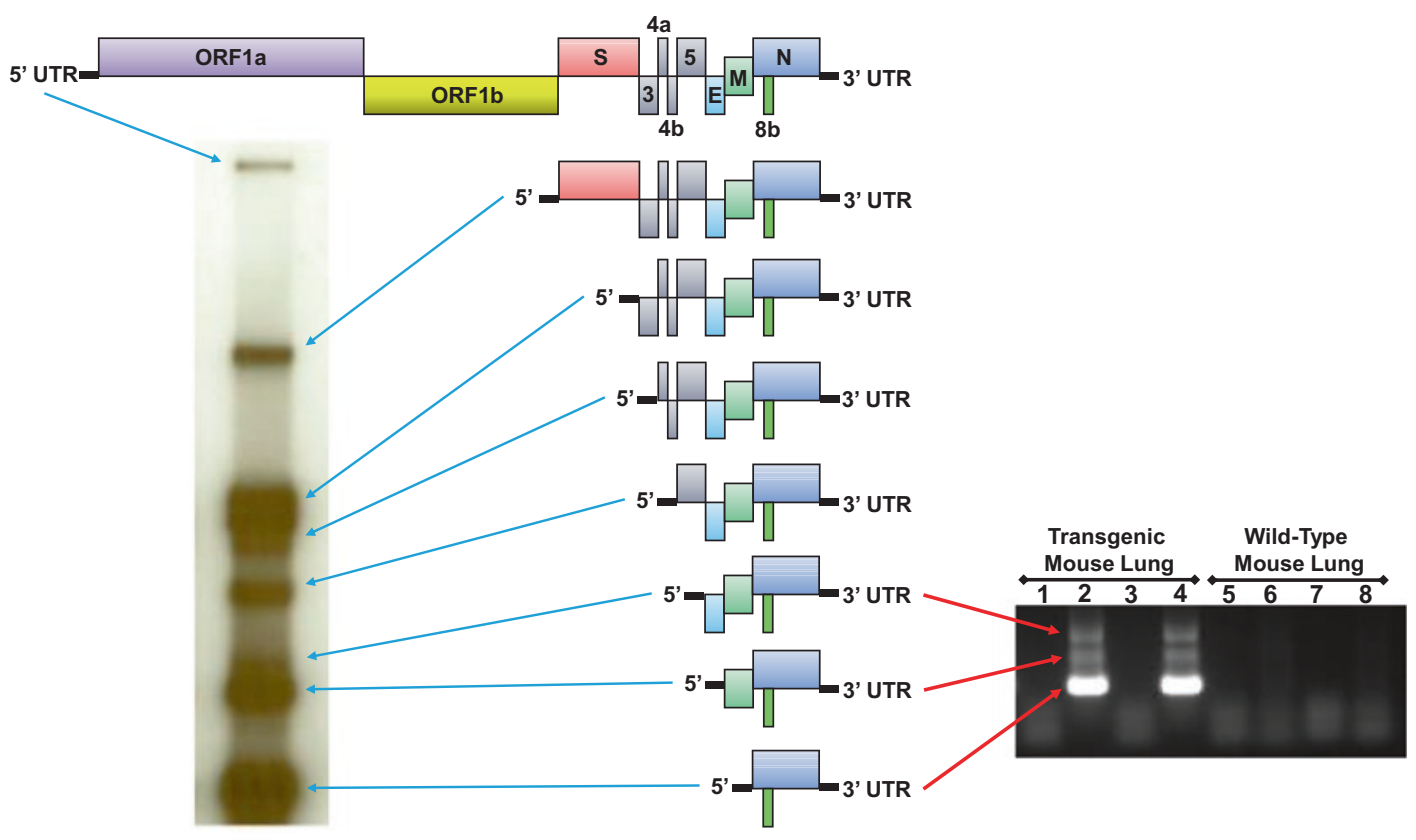

Fig. 4 MERS-CoV subgenomic RNA (sgRNA). sgRNA is generated during active coronavirus replication and can be visualized by northern blot (left) and PCR (right). Using a biotinylated or radioactive probe against the CoV N-gene, all sgRNA species can be visualized by running RNA isolated from CoV-infected cells on a northern gel (left). Northern blot image is reprinted from [25]. Alternately, PCR primers contained within the leader sequence and $\mathrm{N}$-gene can be used to generate PCR products from viral cDNA in order to visualize sgRNA, signifying productive CoV replication (right). Here, PCR products confirm productive replication of MERS-CoV in the lungs of a mouse permissive to MERS-CoV infection (transgenic mouse lung), but not in a nonpermissive, wild-type mouse lung. Both of these methods can be used to confirm productive CoV replication following RGS clone generation

Finally, our group has applied this approach to generate stable molecular clones for flaviviruses that include dengue and the newly emerged Zika virus [31, 32].

Importantly, fragmenting $\mathrm{HCoV}$ genomes confers additional biological safety benefits over reverse genetics systems that would otherwise maintain a $\mathrm{CoV}$ genome as a cDNA molecule comprising greater than $2 / 3$ of the full-length genome. As sanctioned by "NIH Guidelines for Research Involving Recombinant or Synthetic Nucleic Acid Molecules (NIH Guidelines), April, 2016" Section III-E-1 indicates that "Recombinant or synthetic nucleic acid molecules containing no more than two-thirds of the genome of any eukaryotic virus may be propagated and maintained in cells in tissue culture using BLl containment." Moreover, full-length $\mathrm{CoV}$ genomes that encode select agents such as SARS-CoV are further regulated under the Federal Select Agent Program (www.selectagents.gov), and must be handled according to specific guidelines. 
Partitioning the SARS-CoV genome allows for efficient handling of genomic fragments under standard $\mathrm{BSLl} / 2$ containment conditions (Fig. 2). For reconstruction of full-length genomes encoding CoVs restricted to BSL3 containment (SARS-CoV, MERS-CoV, preemergent bat $\mathrm{CoVs}$ ), fragment ligation and all subsequent steps are executed under BSL3 conditions, including recovery of recombinant viruses (Fig. 2).

\subsection{Applications of the Reverse Genetics Platform}

One advantage of a segmented molecular clone design is that mutagenesis can occur in parallel on multiple fragments, and that the individual fragments can be "reassorted" to make larger panels of derivative mutants encoding mutation subsets (Fig. 2). For example, an early application included the introduction of over 27 mutations into the SARS-CoV genome at 9 different genome transcription regulatory sequences, thereby demonstrating for the first time that the transcription regulatory circuit of a virus could be rewired [33]. The applicability of the RGS was ratified in ensuing reports describing the cause-and-effect relationship between site-directed mutations introduced into the viral genome which altered viral fitness and in vivo pathogenesis phenotypes [17, 18, 33-36].

In a seminal pathogenesis study RGS was used to validate that six mutations acquired during mouse adaptation of the SARS-CoV Urbani (MA15) strain indeed caused lung pathology associated with severe acute respiratory distress syndrome [18]. Since these mutations were dispersed across the entire genome, RGS proved to be an efficient method to introduce all six mutations simultaneously in order to generate a robust mouse-adapted SARS-CoV strain. Notably, because MAI5 SARS-CoV is a novel virus strain, RGS is an effective method to validate Koch's postulates by demonstrating a causeand-effect relationship. After nearly a decade of research the MAl5 strain continues to play a dominant role in SARS-CoV mouse pathogenesis studies, including vaccine and therapeutic evaluations [7, 17, 37-39]. In today's research environment these studies would be considered gain-of-function (GOF) studies, and thereby would have been subject to increased government oversight, which would have inevitably stymied progress into understanding the molecular mechanisms governing emerging coronavirus pathogenesis, host range, receptor usage, virus replication, and vaccine and therapeutic efficacy [3]. Notably, SARS-CoV gain-of-function (GOF) studies have yielded invaluable information regarding the role of viral proteins in pathogenesis in animal models and in tissue culture studies $[17,36]$. Applying the combined technologies of GOF studies with the RGS will be essential to future research on emergent and preemergent coronaviruses.

More recently RGS applications were extended to MERS-CoV wherein a replication-competent MERS-CoV expressing the tomato red fluorescent protein (tRFP) was rapidly generated (reproduced from [25]) (Fig. 5). The infectious clone (icMERS-CoV-tRFP) has 


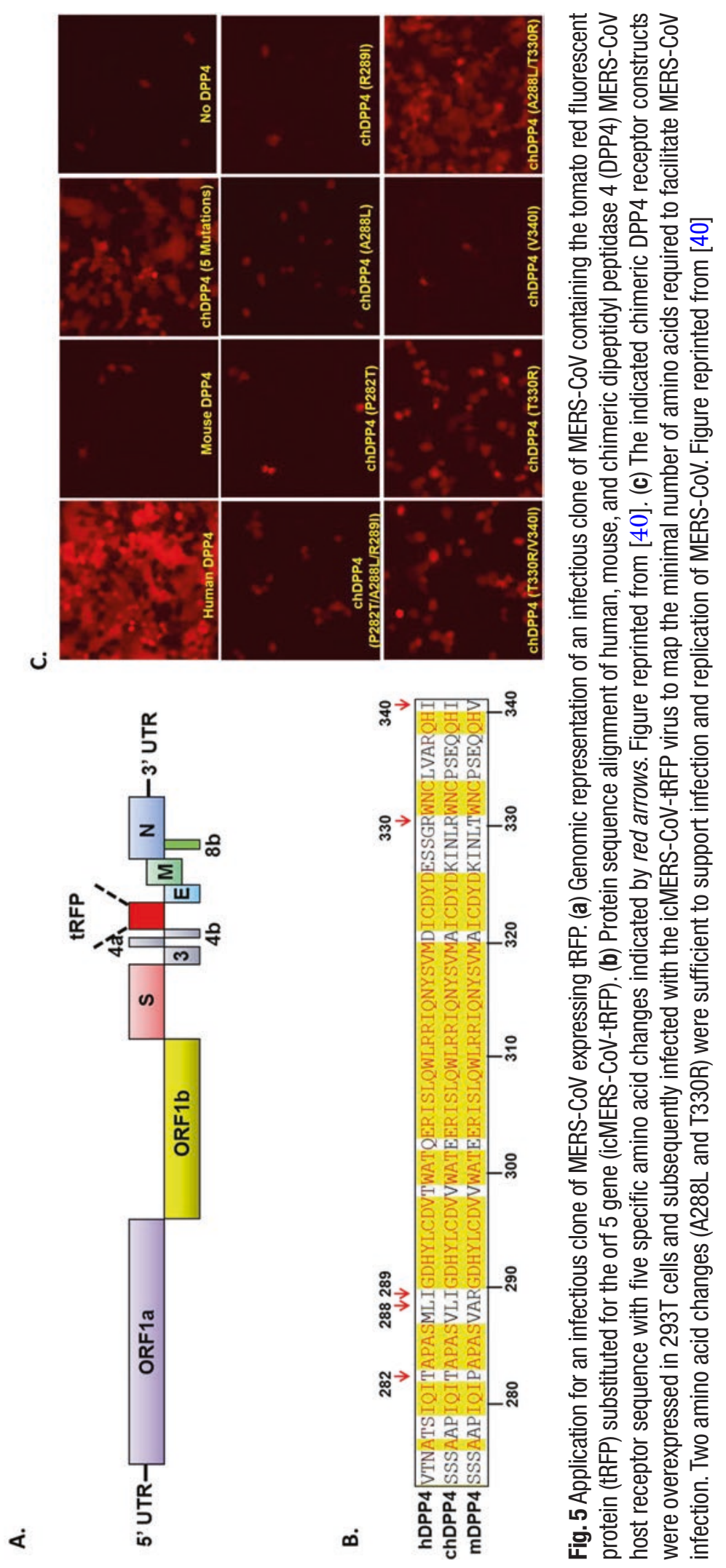


since been applied to understanding host factors that restrict MERS$\mathrm{CoV}$ infection $[40,41]$. Figure 5 demonstrates how the icMERS$\mathrm{CoV}$-tRFP was used to facilitate mapping of specific amino acids in the host dipeptidyl peptidase 4 (DPP4) receptor that are necessary to permit MERS-CoV infection and replication [40]. Humanizing the mouse DPP4 by changing a minimum of two amino acids (A288L and T330R) on the mouse DPP4 protein conferred efficient infection/replication of MERS-CoV as determined by expression of tRFP from the icMERS-CoV-tRFP virus (Fig. 5) [40]. The following protocol outlines the RGS used to generate infectious clones of MERS-CoV, and provides detailed methods for building recombinant coronaviruses using this technique.

\section{Materials}

\subsection{Transformation and Restriction Screening of the Seven MERS- CoV Fragments}

1. Seven plasmids containing MERS fragments A-F cloned into pCR-XL-TOPO (Invitrogen, Carlsbad, CA) or pUC57 vectors.

2. Appropriate restriction enzymes and buffers for screening each MERS fragment (see Table 1).

3. Chemically competent bacterial cells (Top 10, Invitrogen).

4. LB broth supplemented with carbenicillin $(100 \mu \mathrm{g} / \mathrm{mL})$ or kanamycin $(50 \mu \mathrm{g} / \mathrm{mL})$ for growth of bacterial cells following plasmid transformation.

5. LB plates supplemented with carbenicillin $(100 \mu \mathrm{g} / \mathrm{mL})$ or kanamycin $(50 \mu \mathrm{g} / \mathrm{mL})$ for growth of bacterial cells following plasmid transformation.

6. Qiaprep Spin Miniprep Kit (Qiagen).

\section{Table 1}

\section{Fragmenting the MERS-CoV genome over seven plasmids}

\begin{tabular}{llllll}
\hline Fragment & Plasmid vector & Antibiotic & $\begin{array}{l}\text { Flanking restriction } \\
\text { sites } \mathbf{5}^{\prime} \mathbf{3}^{\prime}\end{array}$ & $\begin{array}{l}\text { Restriction } \\
\text { digest buffer }\end{array}$ & $\begin{array}{l}\text { Insert } \\
\text { length (bp) }\end{array}$ \\
\hline MERS-A & pUC57 & Carbenicillin & NruI $^{\text {a }, ~ B g l ~ I ~}$ & NEBuffer 3.1 & 4692 \\
\hline MERS-B & pUC57 & Carbenicillin & Bgl I, Bgl I & NEBuffer 3.1 & 4118 \\
\hline MERS-C & pUC57 & Carbenicillin & Bgl I, Bgl I & NEBuffer 3.1 & 3446 \\
\hline MERS-D1 & pCR-XL-TOPO & Kanamycin & Bgl I, Bgl I & NEBuffer 3.1 & 3211 \\
\hline MERS-D2 & pCR-XL-TOPO & Kanamycin & Bgl I, Bgl I & NEBuffer 3.1 & 3335 \\
\hline MERS-E & pUC57 & Carbenicillin & Bgl I, Bgl I & NEBuffer 3.1 & 5590 \\
\hline MERS-F & pUC57 & Carbenicillin & Bgl I, Not I & NEBuffer 3.1 & 5721 \\
\hline
\end{tabular}

Each genomic fragment is indicated with its corresponding plasmid backbone, the antibiotic used for plasmid selection, the restriction enzymes and buffer used for cloning each fragment, and the length of each MERS-CoV-encoded fragment ${ }^{a}$ Available as high-fidelity enzymes from New England BioLabs, and digested in CutSmart Buffer 


\subsection{Amplification and Digestion of MERS-CoV Fragments}

7. Gel electrophoresis-grade agarose.

8. TAE buffer: $40 \mathrm{mM}$ Tris ( $\mathrm{pH} 7.6), 20 \mathrm{mM}$ acetic acid, $1 \mathrm{mM}$ EDTA.

9. Ethidium bromide, or other DNA-visualizing dye.

10. DNA ladder that allows for determination of fragment size.

11. Transilluminator and gel documentation system for imaging and recording resolved DNA and RNA.

12. DNA gel electrophoresis equipment.

1. Appropriate restriction enzymes and buffers for digestion of each MERS fragment (Table 1).

2. Calf intestinal phosphatase (CIP) for fragment cloning.

3. LB broth supplemented with ampicillin $(75 \mu \mathrm{g} / \mathrm{mL})$ or kanamycin $(50 \mu \mathrm{g} / \mathrm{mL})$ for growth of bacterial cells.

4. Qiaprep Spin Miniprep Kit (Qiagen).

5. Gel electrophoresis-grade agarose.

6. Ethidium bromide, or other DNA-visualizing dye.

7. TAE buffer: $40 \mathrm{mM}$ Tris ( $\mathrm{pH} 7.6), 20 \mathrm{mM}$ acetic acid, $1 \mathrm{mM}$ EDTA.

8. DNA gel electrophoresis and imaging equipment.

9. Transilluminator and gel documentation system for imaging and recording resolved DNA and RNA.

10. Blue light gel imager (Dark Reader) to extract DNA bands from gel.

11. QIAquick Gel Extraction Kit (Qiagen).

12. $3 \mathrm{M}$ Sodium acetate, $\mathrm{pH}$ 5-6.

13. Chloroform.

14. Molecular grade $\mathrm{H}_{2} \mathrm{O}$.

2.3 Assembly and Transcription of Viral Genome
1. NanoDrop (ThermoFisher) or DNA spectrophotometer (BioRad).

2. Cut and purify MERS-A to MERS-F fragments.

3. Fragment with SP6 promoter driving expression of MERS N-gene (used for electroporation negative control and carrier RNA).

4. T4 DNA ligase and ligase buffer (New England BioLabs).

5. Molecular grade $\mathrm{H}_{2} \mathrm{O}$.

6. Chloroform.

7. 70 and $95 \%$ ethanol.

8. mMessage mMachine T7 Transcription Kit (Ambion).

9. mMessage mMachine SP6 Transcription Kit (Ambion). 


\subsection{Cell Preparation}

\subsection{Electroporation}

2.6 Cytopathic Effect and Reporter

Detection

\subsection{Confirmation}

1. Vero-81 cells-approximately $1 \times 10^{7}$ Vero- 81 cells or roughly three $80-90 \%$ confluent T-175 flasks are necessary for one MERS clone and one control electroporation.

2. Ice-cold molecular grade, RNase free $1 \times$ PBS (Gibco).

3. Mammalian cell maintenance medium: $2 \times$ DMEM (Gibco), $10 \%$ fetal bovine serum (Gibco), $1 \times$ antibiotic-antimycotic cocktail (Gibco).

4. $0.25 \%$ Trypsin/EDTA (Sigma).

1. BioRad gene Pulser Excel electroporator or similar device.

2. One $0.4 \mathrm{~cm}$ Gene Pulser cuvette per electroporation.

3. Transcribed full-length viral RNA and cells prepared according to Subheadings. 3.3 and 3.4.

4. Virus harvest medium: OptiMEM, 3\% HyClone II fetal bovine serum, $1 \times$ antibiotic-antimycotic cocktail, $1 \times$ nonessential amino acids, $1 \times$ sodium pyruvate.

1. Light microscope with optional fluorescence capacity.

1. Trizol (Invitrogen)

2. SuperScript II Reverse Transcription kit (Invitrogen)

3. Agarose overlay: Mix agar and media 1:1 prior to overlay.

(a) SeaKem LE agarose (Lonza)-1.6\% agar in $\mathrm{ddH}_{2} \mathrm{O}$.

(b) $2 \times$ MEM-supplemented with $3 \%$ fetal bovine serum (Gibco) and $2 \%$ antibiotic-antimycotic.

4. $10 \times$ Neutral red stain: $0.5 \%$ Neutral red, $0.85 \% \mathrm{NaCl}$ in $\mathrm{dd}_{2} \mathrm{O}$. Alternately stir and incubate in $55^{\circ} \mathrm{C}$ water bath until dissolved, and then filter sterilize. Dilute in IXPBS for working stock.

5. Light box for ease of plaque visualization and counting.

6. PCR primers designed to the leader and $\mathrm{N}$ gene sequence (designed for detection of sgRNA transcripts).

\section{Methods}

\subsection{Transformation and Screening of the Seven MERS- CoV Fragments (BSL1/ BSL2 Biocontainment)}

1. Thaw each MERS plasmid and chemically competent cells ( $50 \mu \mathrm{L}$ aliquots, one tube per plasmid) on ice for $10 \mathrm{~min}$. On ice, add $50 \mathrm{ng}$ (appx. $1 \mu \mathrm{L}$ ) of plasmid to a corresponding labeled tube of competent cells and mix gently. Incubate on ice for $30 \mathrm{~min}$.

2. Heat shock cells in a $42{ }^{\circ} \mathrm{C}$ water bath for $\sim 1 \mathrm{~min}$, return to ice, and incubate for $2 \mathrm{~min}$. 
3.2 Amplification and Digestion of MERS-CoV Fragments (BSL1) BSL2 Biocontainment)
3. Add $500 \mu \mathrm{L}$ of LB broth (without antibiotic) to each competent cell tube. Rock gently at room temperature for $1-6 \mathrm{~h}$.

4. Using a sterile cell spreader, inoculate an appropriate antibiotic selection plate (Table $\mathrm{l}$ ) with $50 \mu \mathrm{L}$ of transformed cells. Incubate for $24-48$ h at $28-30{ }^{\circ} \mathrm{C}$ ( see Note 1$)$.

5. Pick several colonies per plasmid and transfer into $5 \mathrm{~mL}$ of antibiotic-supplemented LB broth (Table 1). Shake at $28-30{ }^{\circ} \mathrm{C}$ overnight.

6. Create a library plate from the overnight cultures by spotting $5 \mu \mathrm{L}$ of each colony culture onto an appropriate antibioticsupplemented LB plate. Incubate at $28-30{ }^{\circ} \mathrm{C}$ overnight, and then store at $4{ }^{\circ} \mathrm{C}$ for storage up to 4 weeks.

7. With the remaining bacterial culture volume, perform minipreps (Qiagen Miniprep Kit) on each colony culture to isolate DNA for screening according to the manufacturer's protocol. Elute DNA from the column in $60 \mu \mathrm{L}$ of Elution Buffer (Qiagen Miniprep kit) heated to $70{ }^{\circ} \mathrm{C}$.

8. Screen colony DNA via restriction digest with appropriate enzymes (see Table 1 ) according to the manufacturer's instructions in a $20 \mu \mathrm{L}$ reaction volume for $\mathrm{l} \mathrm{h}$.

9. Resolve digested fragments by gel electrophoresis in a $0.8 \%$ agarose gel with ethidium bromide in TAE buffer to validate correct-size fragment. $1 \mathrm{~kb}$ DNA ladder or equivalent should be resolved in independent well to validate fragment size. Voltage and time are dependent upon system.

10. Image and document gel for records.

11. Sequence verify colonies with the correct insert prior to advancing to ligation and synthesis of genome-length RNA. Sequencing primers should be spaced approximately 300 nucleotides apart along the $\mathrm{CoV}$ fragment of interest. Primers should also be designed to sequence from the plasmid backbone into the inserted $\mathrm{CoV}$ fragment.

1. Select a replicate from the plasmid library with the correct insert size and sequence for each MERS-CoV fragment (Fig. 2).

2. Inoculate $20 \mathrm{~mL} \mathrm{LB} /$ antibiotic media from library plate prepared in Subheading 3.1, step 6, and shake overnight at $28-30^{\circ} \mathrm{C}$. This should generate enough DNA to assemble two viral clones.

3. Pellet bacterial cells and isolate plasmid DNA using three Qiagen miniprep columns per culture according to the manufacturer's instructions.

4. Elute DNA from the column in $60 \mu \mathrm{L}$ of elution buffer heated to $70{ }^{\circ} \mathrm{C}$. Combine eluted DNA from each of the three columns in step 3 , resulting in approximately $180 \mu \mathrm{L}$ of plasmid DNA per fragment. 
5. Digest plasmid DNA with appropriate restriction enzymes (see Table 1).

(a) MERS-A and MERS-F should first be digested with NruI and NotI for $1 \mathrm{~h}$, respectively, according to the manufacturer's instructions ( see Note 2).

(b) CIP treat fragments by adding 1 unit of CIP per $20 \mu \mathrm{L}$ of digestion volume and incubate at $37^{\circ} \mathrm{C}$ for $1 \mathrm{~h}$.

(c) For each reaction, extract DNA by mixing 4 volumes of DNA digestion reaction with 1 volume of $3 \mathrm{M}$ sodium acetate and 5 volumes of chloroform. Mix by inversion for 2 min and separate aqueous/organic phases by centrifuging at max speed for $4-5 \mathrm{~min}$ at $4{ }^{\circ} \mathrm{C}$.

(d) Remove the aqueous layer to a clean, labeled tube and add six volumes of isopropyl alcohol. Mix and incubate at room temperature for $10 \mathrm{~min}$.

(e) Pellet DNA by centrifugation at max speed for $10 \mathrm{~min}$.

(f) Remove the supernatant, add $1 \mathrm{~mL}$ of ice-cold $70 \%$ ethanol per tube, and repeat centrifugation.

(g) Carefully remove the supernatant, add $1 \mathrm{~mL}$ of ice-cold 95\% ethanol per tube, and repeat centrifugation.

(h) Carefully remove supernatant and allow DNA pellet to air-dry until no ethanol remains.

(i) Suspend pellet in molecular grade $\mathrm{H}_{2} \mathrm{O}$ heated to $70{ }^{\circ} \mathrm{C}$.

(j) Continue with digestion of MERS-A and MERS-F, linearized plasmids, with BglI for $1 \mathrm{~h}$ according to the manufacturer's instructions.

(k) Digest plasmids containing MERS fragments B through E with BglI for $1 \mathrm{~h}$ according to the manufacturer's instructions.

6. Isolate fragments by gel electrophoresis in a $0.8 \%$ agarose gel with ethidium bromide. Allow gel to run until a distinct and easily isolated insert of interest can be seen (see Notes 3 and 4).

7. Remove the band of interest for each fragment (see Table 1).

8. Purify each fragment from the gel using a QIAquick Gel Extraction Kit, according to the manufacturer's instructions. Bands of the same fragment may be pooled and extracted together.

9. Chloroform extract each gel-purified fragment (steps $\mathbf{5 c - i}$ ).

3.3 Assembly and Transcription of Viral Genome (BSL3 Biocontainment)
1. Quantitate the DNA fragments using a DNA spectrophotometer or NanoDrop, and use the base pair length of each fragment to determine the molecule copy number [number of copies $=($ ng of insert DNA $\times 6.022 \times 10^{23}$ molecules $\left./ \mathrm{mol}\right) /($ insert length in base pairs $\left.\left.\times 1 \times 10^{9} \times 650 \mathrm{~g} / \mathrm{mol}\right)\right]$. 
3.4 Cell Preparation (BSL2 Biocontainment)

3.5 Electroporation (BSL3 Biocontainment)
2. Mix an approximately equal copy number of each fragment in a single $1.5 \mathrm{~mL}$ Eppendorf tube with a final total volume of 300-400 $\mu \mathrm{L}$ (approx. 20-40 $\mu \mathrm{L}$ per fragment). Add $1 \mu \mathrm{L}$ $10 \times$ ligase buffer and $0.5 \mu \mathrm{L}$ of ligase per $10 \mu \mathrm{L}$ of final DNA ligation volume. Incubate the ligation reaction overnight at $4{ }^{\circ} \mathrm{C}($ see Note 5$)$.

3. Perform a chloroform extraction of the ligation reaction (Subheading 3.2, steps $\mathbf{5} \mathbf{c}-\mathbf{i}$ ), resuspending the final DNA pellet in $10-12 \mu \mathrm{L}$ of DEPC $\mathrm{H}_{2} \mathrm{O}$ (see Note 6).

4. Full-length transcription is performed using the mMessage mMachine T7 transcription kit according to the manufacturer's instructions.

(a) Combine $10 \mu \mathrm{L}$ MERS-CoV ligated DNA, $8 \mu \mathrm{L}$ GTP, $6 \mu \mathrm{L} 10 \times \mathrm{T} 7$ buffer, $30 \mu \mathrm{L} 2 \times \mathrm{NTP} / \mathrm{CAP}$, and $6 \mu \mathrm{L}$ of T7 enzyme.

5. MERS N-gene transcript will be used as a negative control for electroporation and as a carrier RNA co-electroporated with full-length viral RNA transcript generated in step 4. MERS $\mathrm{N}$-gene transcript is generated with mMessage mMachine SP6 Transcription Kit according to the manufacturer's instructions (see Note 7).

(a) Combine $9 \mu \mathrm{L}$ template DNA, $9 \mu \mathrm{L}$ molecular grade $\mathrm{H}_{2} \mathrm{O}$, $6 \mu \mathrm{L} \mathrm{10 \times SP6} \mathrm{buffer,} 30 \mu \mathrm{L} 2 \times \mathrm{NTP} / \mathrm{CAP}$, and $6 \mu \mathrm{L}$ SP6 enzyme.

6. Incubate the transcription reactions at $32{ }^{\circ} \mathrm{C}$ for $4-6 \mathrm{~h}$ (see Notes $\mathbf{8}$ and $\mathbf{9}$ ).

1. Vero-81 cells should be $80-90 \%$ confluent on the day of electroporation. Cells are maintained in maintenance medium (see Subheading 2.4).

2. To prepare for electroporation, remove media and wash cells in $1 \times$ PBS. Add $3 \mathrm{~mL}$ of $0.25 \%$ trypsin/EDTA (per T- 175 flask) and incubate at $37^{\circ} \mathrm{C}$ until the cells detach from the flask (see Note 10).

3. Add $7 \mathrm{~mL}$ of maintenance medium per T- 175 flask to the trypsinized cells, and then transfer to a $50 \mathrm{~mL}$ conical tube. Pellet cells at $2000 \times g$ for $5 \mathrm{~min}$ at $4{ }^{\circ} \mathrm{C}($ see Notes 6 and 11$)$.

4. Suspend cells in $10 \mathrm{~mL}$ of ice-cold sterile, molecular grade $1 \times$ PBS. Count cells using a hemocytometer and pellet cells as in step 3. Repeat $1 \times$.

5. Suspend cell pellet in ice-cold sterile $1 \times$ PBS to a final concentration of $\sim 10^{7}$ cells $/ \mathrm{mL}$.

1. Add $60 \mu \mathrm{L}$ of full-length MERS-CoV RNA (Subheading 3.3, step 4) and $20 \mu \mathrm{L}$ of N-gene transcript (Subheading 3.3, step 5) to a microfuge tube. Quickly add $800 \mu \mathrm{L}$ of ice-cold cell suspension and pipette up and down twice (see Note 12). 
2. For the electroporation negative control use the remainder of $\mathrm{N}$-gene transcript (Subheading 3.3, step 5) and add $800 \mu \mathrm{L}$ of ice-cold Vero-81 cell suspension.

3. Immediately transfer cuvette to a BioRad Gene Pulser Excel electroporator, or a similar device, and set to $50 \mu \mathrm{F}$ and 450 V. Pulse three times.

4. Remove cuvette and allow to sit at room temperature, without agitation, for $10 \mathrm{~min}$.

5. Transfer electroporated cells to a prepared T-75 flask with $12 \mathrm{~mL}$ of harvest medium at $37^{\circ} \mathrm{C}$. Gently rock cells to allow for even distribution. Check for cytopathic effects against the electroporation control over the next $48 \mathrm{~h}$.

3.6 Cytopathic Effect and Reporter Detection (BSL3 Biocontainment)

3.7 Confirmation (BSL2 and BSL3 Containment)
1. Wild-type MERS-CoV will produce cytopathic effects within 24-72 h (Fig. 3). Syncytia formation results from fusion of neighboring cells via an excess of spike glycoprotein, and can be seen within 12-48 h of electroporation (Fig. 3) (see Note 13).

2. MERS-CoV can typically be harvested within $48-72$ h postelectroporation. Virus harvested just before complete loss of the cellular monolayer will result in $10^{7}-10^{8}$ PFU of MERSCoV per mL of culture medium (see Note 14).

3 . If a fluorescent reporter has been inserted in place of an accessory gene open reading frame, then cytopathic effects, viral spread, and confirmation of viral replication can be visualized with a fluorescent microscope (Fig. 5).

4. Clarify viral supernatant by spinning at $3000 \times g$ for $15-20 \mathrm{~min}$.

5. Aliquot samples into labeled tubes and store at $-80{ }^{\circ} \mathrm{C}$. This viral stock is passage 0 ( see Notes 15-17).

1. Virus titration by plaque assay (BSL3 Containment) (Fig. 3):

(a) MERS-CoV can be titered by plaque assay. $24 \mathrm{~h}$ prior to initiating plaque assay seed 3 six-well plates with $5 \times 10^{5}$ Vero-81 cells per well using standard maintenance media.

(b) Serial dilute virus stocks at $10^{-1}$ to $10^{-8}$ in $1 \times$ PBS to ensure identification of an appropriate dilution to accurately count plaques.

(c) Add $200 \mu \mathrm{L}$ of the appropriate dilution to each of the two wells and incubate at $37{ }^{\circ} \mathrm{C}$ for $\mathrm{l} \mathrm{h}$. Rock plates every $15 \mathrm{~min}$ to ensure even distribution of virus inoculum across monolayer.

(d) Overlay each well with $2 \mathrm{~mL}$ of $0.8 \%$ agar/media cocktail (see Subheading 2) ( see Note 18).

(e) Plaques are visible and can be stained or picked for plaque purification after $72 \mathrm{~h}$. 
(f) To stain, add $2 \mathrm{~mL}$ of neutral red stain (see Subheading 2) per well and incubate at $37^{\circ} \mathrm{C}$ for $2-3 \mathrm{~h}$. Remove neutral red and visualize plaques over a light box to count and titer.

2. Growth curve to assess viral fitness (BSL3 Containment) (Fig. 3):

(a) Seed a 12-well tissue culture plate with a known number of Vero-81 cells at $24 \mathrm{~h}$ prior to infection.

(b) Infect cells at a low MOI (0.01-0.001).

(c) Incubate at $37^{\circ} \mathrm{C}$ for $1 \mathrm{~h}$ rocking plate every $15 \mathrm{~min}$ for even distribution of virus inoculum across monolayer.

(d) Remove supernatant, wash cells with $1 \times$ PBS, and add fresh maintenance medium.

(e) Collect small aliquots of supernatant at time points of interest $(0,4,8,12,24,48$, and 72 h post-infection) to determine viral fitness and growth dynamics.

(f) Aliquots should be titered via plaque assay as described above (see Note 19).

3. Verification of viral RNA (Fig. 4):

(a) Viral RNA can be collected from infected cells, or viral particles, using Trizol, according to the manufacturer's instructions (see Note 20 for handling RNA).

(b) Reverse transcribe $1 \mu \mathrm{g}$ of total RNA using a SuperScript II RT kit according to the manufacturer's instructions to generate cDNA.

(c) Complementary DNA can be verified using PCR designed to identify viral mutants, or sequenced in order to verify viral sequence fidelity.

(d) PCR of cDNA can also be used to confirm the presence of replication-competent virus by designing a primer to the leader in the $5^{\prime}$ end and an ORF near the $3^{\prime}$ end of the genome, such as that encoding the $\mathrm{N}$ gene ( see Note 21 ).

(e) Northern blot can likewise be used to identify the presence of CoV sgRNA using the Ambion NorthernMax-Gly kit.

(f) For detection, design a biotinylated probe against the $\mathrm{N}$ gene, located at the $3^{\prime}$ end of the genome, allowing for detection of all viral RNA species present in infected cells. Biotinylated probe should be complementary to the coding strand.

\section{Notes}

1. Lowering the growth temperature of the bacteria helps to reduce plasmid copy number, thereby increasing plasmid stability in instances where the inserted fragment is toxic. 
2. It is important to initially digest, and CIP treat, MERS-A and MERS-F fragments with flanking restriction to prevent inadvertent formation of concatemers and ensure seamless assembly of all fragments.

3. Do not use a UV box to visualize DNA inserts that will be used to create the final full-length DNA genome. UV will introduce random mutations into the inserts that can prevent viral replication and will reduce sequence fidelity. Instead, use a blue-light (dark reader) based transilluminator box to visualize and cut out inserts.

4. Because of the large volume of digested plasmid to be resolved, a gel apparatus should allow for 50-75 $\mu \mathrm{L}$ volumes per well.

5. All steps prior to fragment assembly can be executed under BSL1/BSL2 conditions. MERS-CoV ligation and subsequent steps must be performed in a biosafety level three containment lab.

6. From this point on all working environments should be RNase free. All reagents should be treated with RNase Zap, or similar treatment, to avoid contamination with RNase.

7. Co-electroporation of full-length viral RNA and capped $\mathrm{N}$-gene mRNA has been shown to enhance the transfection efficiency of $\mathrm{CoV}$ full-length transcripts.

8. Generally, transcription reactions are performed for a short time at $37^{\circ} \mathrm{C}$. However, in order to ensure the full transcription of all $30 \mathrm{~kb}$ of the genome, and to promote sequence fidelity, a lower temperature and longer reaction time are executed.

9. Because of the relative instability of RNA, the full-length transcription reaction should be performed on the same day as the electroporation, typically 5-6 h prior to electroporation.

10. Cells should detach through trypsin digestion and not through physical agitation, as a clean single-cell suspension is desired for efficient electroporation.

11. All subsequent steps should be performed on ice or in a refrigerated centrifuge.

12. Each electroporation cocktail (RNA and cells) should be prepared one at a time. Each subsequent reaction should be prepared following electroporation of the previously prepared cocktail.

13. Successful generation of viral RNA and electroporation will result in loss of cell adherence and cell death within 24-72 h of electroporation. The range of times indicated will depend on the infectious clone being generated.

14. Mutant viruses may take longer to show cytopathic effects and may result in lower overall viral titer. If particularly deleterious 
mutations have been introduced, cytopathic effects may not be seen, and a secondary means of confirmation will be required to assess the success of virus generation. Additional means of confirmation may include staining with antibody and visualizing by immunofluorescence microscopy or isolating total RNA from cell lysates to confirm by RT-PCR.

15. If deleterious mutations have been introduced during cloning, be sure to sequence verify passage 0 and subsequent virus passages, preferentially using $\mathrm{P} 0$ virus to assure sequence fidelity.

16. Expanding viral stocks by passage through cell culture can lead to the natural accumulation of tissue culture-adapted mutations. Viral stocks should routinely be sequence validated.

17. Freezing and thawing virus will result in an approximate log drop in titer for each freeze-thaw cycle.

18. Plates should not be disturbed (i.e., moved) during incubation to ensure clear identification of plaques.

19. It is recommended to run wild-type virus and a non-mutated infectious clone virus as controls for a growth curve of any reverse genetics mutant.

20. At the time of writing this chapter MERS-CoV genomic length RNA is not considered a select agent. Therefore, samples can be inactivated in Trizol under BSL3 conditions, and then moved to BSL2 for subsequent work. In the case of select agents, like SARS-CoV, the handling of genomic length RNA falls under the Federal Select Agent Program, and must be handled accordingly.

21. During replication, CoVs generate a nested set of sgRNA intermediates containing the leader sequence at the $5^{\prime}$ end, a portion of the ORFs present in the CoV genome, and a $3^{\prime}$ UTR (Fig. 4). As a result, primers built into the leader sequence and the $\mathrm{N}$-gene will generate PCR products of various lengths representing the cDNA from both full-length and sgRNA. If the presence of sgRNA is detected, it can be assumed that the $\mathrm{CoV}$ clone is infectious and replication competent.

\section{References}

1. McIntosh K (2005) Coronaviruses in the limelight. J Infect Dis 191(4):489-491. doi:10.1086/428510

2. Peiris JS, Guan Y, Yuen KY (2004) Severe acute respiratory syndrome. Nat Med 10(12 Suppl):S88-S97. doi:10.1038/nml143

3. Graham RL, Donaldson EF, Baric RS (2013) A decade after SARS: strategies for controlling emerging coronaviruses. Nat Rev Microbiol 11(12):836-848. doi:10.1038/nrmicro3143
4. Gralinski LE, Baric RS (2015) Molecular pathology of emerging coronavirus infections. J Pathol 235(2):185-195. doi:10.1002/ path. 4454

5. Channappanavar R, Zhao J, Perlman S (2014) T cell-mediated immune response to respiratory coronaviruses. Immunol Res 59(1-3):118-128. doi:10.1007/s12026-014-8534-Z

6. Totura AL, Baric RS (2012) SARS coronavirus pathogenesis: host innate immune responses 
and viral antagonism of interferon. Curr Opin Virol 2(3):264-275. doi:10.1016/j.coviro. 2012.04.004

7. Gralinski LE, Ferris MT, Aylor DL, Whitmore AC, Green R, Frieman MB, Deming D, Menachery VD, Miller DR, Buus RJ, Bell TA, Churchill GA, Threadgill DW, Katze MG, McMillan L, Valdar W, Heise MT, PardoManuel de Villena F, Baric RS (2015) Genome wide identification of SARS-CoV susceptibility loci using the collaborative cross. PLoS Genet 11(10):e1005504. doi:10.1371/journal.pgen. 1005504

8. Fouchier RA, Hartwig NG, Bestebroer TM, Niemeyer B, de Jong JC, Simon JH, Osterhaus AD (2004) A previously undescribed coronavirus associated with respiratory disease in humans. Proc Natl Acad Sci U S A 101(16):6212-6216. doi:10.1073/pnas.0400762101

9. van der Hoek L, Pyrc K, Jebbink MF, Vermeulen-Oost W, Berkhout RJ, Wolthers KC, Wertheim-van Dillen PM, Kaandorp J, Spaargaren J, Berkhout B (2004) Identification of a new human coronavirus. Nat Med 10(4):368-373. doi:10.1038/nml024

10. Woo PC, Lau SK, Chu CM, Chan KH, Tsoi HW, Huang Y, Wong BH, Poon RW, Cai JJ, Luk WK, Poon LL, Wong SS, Guan Y, Peiris JS, Yuen KY (2005) Characterization and complete genome sequence of a novel coronavirus, coronavirus HKUl, from patients with pneumonia. J Virol 79(2):884-895. doi:10.1128/ JVI.79.2.884-895.2005

11. van den Brand JM, Smits SL, Haagmans BL (2015) Pathogenesis of Middle East respiratory syndrome coronavirus. J Pathol 235(2):175-184. doi:10.1002/path.4458

12. Lee SI (2015) Costly lessons from the 2015 Middle East respiratory syndrome coronavirus outbreak in Korea. J Prev Med Public Health 48(6):274-276. doi:10.3961/jpmph.15.064

13. de Wit E, van Doremalen N, Falzarano D, Munster VJ (2016) SARS and MERS: recent insights into emerging coronaviruses. Nat Rev Microbiol 14(8):523-534. doi:10.1038/ nrmicro.2016.81

14. Stevenson GW, Hoang H, Schwartz KJ, Burrough ER, Sun D, Madson D, Cooper VL, Pillatzki A, Gauger P, Schmitt BJ, Koster LG, Killian ML, Yoon KJ (2013) Emergence of Porcine epidemic diarrhea virus in the United States: clinical signs, lesions, and viral genomic sequences. J Vet Diagn Invest 25(5):649-654. doi:10.1177/1040638713501675

15. Ge XY, Li JL, Yang XL, Chmura AA, Zhu G, Epstein JH, Mazet JK, Hu B, Zhang W, Peng C, Zhang YJ, Luo CM, Tan B, Wang N, Zhu Y, Crameri G, Zhang SY, Wang LF, Daszak P,
Shi ZL (2013) Isolation and characterization of a bat SARS-like coronavirus that uses the ACE2 receptor. Nature 503(7477):535-538. doi:10.1038/nature 12711

16. Yount B, Curtis KM, Fritz EA, Hensley LE, Jahrling PB, Prentice E, Denison MR, Geisbert TW, Baric RS (2003) Reverse genetics with a full-length infectious cDNA of severe acute respiratory syndrome coronavirus. Proc Natl Acad Sci U S A 100(22):12995-13000. doi:10.1073/pnas.1735582100

17. Frieman M, Yount B, Agnihothram S, Page C, Donaldson E, Roberts A, Vogel L, Woodruff B, Scorpio D, Subbarao K, Baric RS (2012) Molecular determinants of severe acute respiratory syndrome coronavirus pathogenesis and virulence in young and aged mouse models of human disease. J Virol 86(2):884-897. doi:10.1128/JVI.05957-11

18. Roberts A, Deming D, Paddock CD, Cheng A, Yount B, Vogel L, Herman BD, Sheahan T, Heise M, Genrich GL, Zaki SR, Baric R, Subbarao K (2007) A mouse-adapted SARScoronavirus causes disease and mortality in BALB/c mice. PLoS Pathog 3(1):e5. doi:10.1371/journal.ppat.0030005

19. Almazan F, Gonzalez JM, Penzes Z, Izeta A, Calvo E, Plana-Duran J, Enjuanes L (2000) Engineering the largest RNA virus genome as an infectious bacterial artificial chromosome. Proc Natl Acad Sci U S A 97(10):5516-5521

20. Yount B, Curtis KM, Baric RS (2000) Strategy for systematic assembly of large RNA and DNA genomes: transmissible gastroenteritis virus model. J Virol 74(22):10600-10611

21. Yount B, Denison MR, Weiss SR, Baric RS (2002) Systematic assembly of a full-length infectious $\mathrm{cDNA}$ of mouse hepatitis virus strain A59. J Virol 76(21):11065-11078. doi:10.1128/jvi.76.21.11065-11078.2002

22. Thiel V, Herold J, Schelle B, Siddell SG (2001) Infectious RNA transcribed in vitro from a cDNA copy of the human coronavirus genome cloned in vaccinia virus. J Gen Virol 82(Pt 6):1273-1281. doi:10.1099/0022-1317-82-6-1273

23. Almazan F, Sola I, Zuniga S, Marquez-Jurado S, Morales L, Becares M, Enjuanes L (2014) Coronavirus reverse genetic systems: infectious clones and replicons. Virus Res 189:262-270. doi:10.1016/j.virusres.2014.05.026

24. Thiel V, Siddell SG (2005) Reverse genetics of coronaviruses using vaccinia virus vectors. Curr Top Microbiol Immunol 287:199-227

25. Scobey T, Yount BL, Sims AC, Donaldson EF, Agnihothram SS, Menachery VD, Graham RL, Swanstrom J, Bove PF, Kim JD, Grego S, Randell SH, Baric RS (2013) Reverse genetics with a full-length infectious cDNA of the 
Middle East respiratory syndrome coronavirus. Proc Natl Acad Sci U S A 110(40):16157-16162. doi:10.1073/pnas.1311542110

26. Rota PA, Oberste MS, Monroe SS, Nix WA, Campagnoli R, Icenogle JP, Penaranda $S$, Bankamp B, Maher $\mathrm{K}$, Chen $\mathrm{MH}$, Tong S, Tamin A, Lowe L, Frace M, DeRisi JL, Chen Q, Wang D, Erdman DD, Peret TC, Burns C, Ksiazek TG, Rollin PE, Sanchez A, Liffick S, Holloway B, Limor J, McCaustland K, OlsenRasmussen $M$, Fouchier R, Gunther S, Osterhaus $\mathrm{AD}$, Drosten C, Pallansch MA, Anderson LJ, Bellini WJ (2003) Characterization of a novel coronavirus associated with severe acute respiratory syndrome. Science (New York, NY) 300(5624):1394-1399. doi:10.1126/ science. 1085952

27. Donaldson EF, Yount B, Sims AC, Burkett S, Pickles RJ, Baric RS (2008) Systematic assembly of a full-length infectious clone of human coronavirus NL63. J Virol 82(23):1194811957. doi:10.1128/JVI.01804-08

28. Becker MM, Graham RL, Donaldson EF, Rockx B, Sims AC, Sheahan T, Pickles RJ, Corti D, Johnston RE, Baric RS, Denison MR (2008) Synthetic recombinant bat SARS-like coronavirus is infectious in cultured cells and in mice. Proc Natl Acad Sci U S A 105(50):1994419949. doi:10.1073/pnas.0808116105

29. Menachery VD, Yount BL Jr, Debbink K, Agnihothram S, Gralinski LE, Plante JA, Graham RL, Scobey T, Ge XY, Donaldson EF, Randell SH, Lanzavecchia A, Marasco WA, Shi ZL, Baric RS (2015) A SARS-like cluster of circulating bat coronaviruses shows potential for human emergence. Nat Med 21(12):15081513. doi:10.1038/nm.3985

30. Menachery VD, Yount BL Jr, Sims AC, Debbink K, Agnihothram SS, Gralinski LE, Graham RL, Scobey T, Plante JA, Royal SR, Swanstrom J, Sheahan TP, Pickles RJ, Corti D, Randell SH, Lanzavecchia A, Marasco WA, Baric RS (2016) SARS-like WIVl-CoV poised for human emergence. Proc Natl Acad Sci U S A 113(11):3048-3053. doi:10.1073/ pnas. 1517719113

31. Gallichotte EN, Widman DG, Yount BL, Wahala WM, Durbin A, Whitehead S, Sariol CA, Crowe JE Jr, de Silva AM, Baric RS (2015) A new quaternary structure epitope on dengue virus serotype 2 is the target of durable type-specific neutralizing antibodies. MBio 6(5):e01461-e01415.

doi:10.1128/ mBio.01461-15

32. Messer WB, Yount B, Hacker KE, Donaldson EF, Huynh JP, de Silva AM, Baric RS (2012) Development and characterization of a reverse genetic system for studying dengue virus serotype 3 strain variation and neutralization. PLoS Negl Trop Dis 6(2):el486. doi:10.1371/ journal.pntd.0001486

33. Yount B, Roberts RS, Lindesmith L, Baric RS (2006) Rewiring the severe acute respiratory syndrome coronavirus (SARS-CoV) transcription circuit: engineering a recombinationresistant genome. Proc Natl Acad Sci U S A 103(33):12546-12551. doi:10.1073/ pnas. 0605438103

34. Curtis KM, Yount B, Baric RS (2002) Heterologous gene expression from transmissible gastroenteritis virus replicon particles. J Virol 76(3):1422-1434. doi:10.1128/ jvi.76.3.1422-1434.2002

35. Frieman M, Yount B, Heise M, KopeckyBromberg SA, Palese P, Baric RS (2007) Severe acute respiratory syndrome coronavirus ORF6 antagonizes STATl function by sequestering nuclear import factors on the rough endoplasmic reticulum/Golgi membrane. J Virol 81(18):9812-9824. doi:10.1128/ JVI.01012-07

36. Yount B, Roberts RS, Sims AC, Deming D, Frieman MB, Sparks J, Denison MR, Davis N, Baric RS (2005) Severe acute respiratory syndrome coronavirus group-specific open reading frames encode nonessential functions for replication in cell cultures and mice. J Virol 79(23):14909-14922.

JVI.79.23.14909-14922.2005

37. Frieman MB, Chen J, Morrison TE, Whitmore A, Funkhouser W, Ward JM, Lamirande EW, Roberts A, Heise M, Subbarao K, Baric RS (2010) SARS-CoV pathogenesis is regulated by a STATl dependent but a type I, II and III interferon receptor independent mechanism. PLoS Pathog 6(4):e1000849. doi:10.1371/ journal.ppat.1000849

38. Sheahan T, Morrison TE, Funkhouser W, Uematsu S, Akira S, Baric RS, Heise MT (2008) MyD88 is required for protection from lethal infection with a mouse-adapted SARS-CoV. PLoS Pathog 4(12):e1000240. doi:10.1371/ journal.ppat.1000240

39. Totura AL, Whitmore A, Agnihothram S, Schafer A, Katze MG, Heise MT, Baric RS (2015) Toll-like receptor 3 signaling via TRIF contributes to a protective innate immune response to severe acute respiratory syndrome coronavirus infection. MBio 6(3):e00638e00615. doi:10.1128/mBio.00638-15

40. Cockrell AS, Peck KM, Yount BL, Agnihothram SS, Scobey T, Curnes NR, Baric RS, Heise MT (2014) Mouse dipeptidyl peptidase 4 is not a functional receptor for Middle East respiratory 
syndrome coronavirus infection. J Virol 88(9):5195-5199. doi:10.1128/JVI.03764-13

41. Peck KM, Cockrell AS, Yount BL, Scobey T, Baric RS, Heise MT (2015) Glycosylation of mouse DPP4 plays a role in inhibiting Middle East respiratory syndrome coronavirus infection. J Virol 89(8):4696-4699. doi:10.1128/JVI.03445-14 